\title{
Nitrogen removal, nitrous oxide emission and microbial community in sequencing batch and continuous-flow intermittent aeration processes
}

\author{
Yuepeng Sun, Liwei Xin, Guangxue $\mathrm{Wu}^{\dagger}$, Yuntao Guan \\ Guangdong Province Engineering Research Center for Urban Water Recycling and Environmental Safety, Graduate School at Shenzhen, Tsinghua \\ University, Shenzhen 518055, China
}

\begin{abstract}
Nitrogen removal, nitrous oxide $\left(\mathrm{N}_{2} \mathrm{O}\right)$ emission and microbial community in sequencing batch and continuous-flow intermittent aeration processes were investigated. Two sequencing batch reactors (SBRs) and two continuous-flow multiple anoxic and aerobic reactors (CMRs) were operated under high dissolved oxygen (DO) (SBR-H and CMR-H) and low DO (SBR-L and CMR-L) concentrations, respectively. Nitrogen removal was enhanced under CMR and low DO conditions (CMR-L). The highest total inorganic nitrogen removal efficiency of 91.5\% was achieved. Higher nitrifying and denitrifying activities in SBRs were observed. CMRs possessed higher $\mathrm{N}_{2} \mathrm{O}$ emission factors during nitrification in the presence of organics, with the highest $\mathrm{N}_{2} \mathrm{O}$ emission factor of $60.7 \%$ in CMR-L. SBR and low DO conditions promoted $\mathrm{N}_{2} \mathrm{O}$ emission during denitrification. CMR systems had higher microbial diversity. Candidatus Accumulibacter, Nitrosomonadaceae and putative denitrifiers $\left(\mathrm{N}_{2} \mathrm{O}\right.$ reducers and producers) were responsible for $\mathrm{N}_{2} \mathrm{O}$ emission.
\end{abstract}

Keywords: Continuous-flow multiple anoxic and aerobic reactor, Intermittent aeration process, Nitrogen removal, Nitrous oxide, Sequencing batch reactor

\section{Introduction}

During biological nitrogen removal from wastewater, ammonia nitrogen $\left(\mathrm{NH}_{4}-\mathrm{N}\right)$ is oxidized sequentially to nitrite nitrogen $\left(\mathrm{NO}_{2}-\mathrm{N}\right)$ by ammonia oxidizing bacteria $(\mathrm{AOB})$ and then to nitrate nitrogen $\left(\mathrm{NO}_{3}-\mathrm{N}\right)$ by nitrite oxidizing bacteria (NOB) under aerobic conditions (nitrification), and following $\mathrm{NO}_{3}-\mathrm{N}$ is reduced to $\mathrm{NO}_{2}-\mathrm{N}$, nitric oxide, nitrous oxide $\left(\mathrm{N}_{2} \mathrm{O}\right)$ and nitrogen gas $\left(\mathrm{N}_{2}\right)$ by denitrifiers under anoxic conditions (denitrification). Particularly, characterized by alternative anoxic for denitrification and aerobic for nitrification, the intermittent aeration process has been widely applied for enhancing nitrogen removal from wastewater. Alternative anoxic and aerobic (AO) conditions can be realized timely within one sequencing batch reactor (SBR) as the intermittent aeration SBR (IASBR) or spatially in sequential reactors as the multiple anoxic and aerobic process [1]. For examples, total inorganic nitrogen (TIN) removal percent- age in IASBR was $38.7 \%$ higher than in the AO SBR system [2]. In the intermittent aeration process, simultaneous nitrification and denitrification (SND) and denitrification with internal organic carbon could be enhanced [2]. In addition, AOB stimulation and NOB inhibition were observed under transition from anoxic to aerobic conditions, inducing partial nitrification [3]. However, $\mathrm{N}_{2} \mathrm{O}$ emission may be triggered with the short-cut nitrogen removal process because $\mathrm{NO}_{2}-\mathrm{N}$ is the precursor of $\mathrm{N}_{2} \mathrm{O}$ production and the inhibitor of nitrous oxide reductase (Nos) [4]. Therefore, $\mathrm{N}_{2} \mathrm{O}$ emission in the intermittent aeration process should be well evaluated.

$\mathrm{N}_{2} \mathrm{O}$ has a high greenhouse potential, with 300 times that of $\mathrm{CO}_{2} \cdot 0.03-18 \%$ of influent total nitrogen (TN) was emitted as $\mathrm{N}_{2} \mathrm{O}$ in intermittent aeration processes (lab-scale and full-scale), and the emission varied depending on the type of treatment processes, water quality, anoxic/aerobic period ratio and dissolved oxygen (DO) concentration [1]. Three pathways
This is an Open Access article distributed under the terms of the Creative Commons Attribution Non-Commercial License (http://creativecommons.org/licenses/by-nc/3.0/) which permits unrestricted non-commercial use, distribution, and reproduction in any medium, provided the original work is properly cited.

Copyright (C) 2019 Korean Society of Environmental Engineers
Received April 11, 2018 Accepted June 20, 2018

${ }^{\dagger}$ Corresponding author

Email: wu.guangxue@sz.tsinghua.edu.cn

Tel: +86-755-26036390 Fax: +86-755-26016511

ORCID: 0000-0003-1982-2998 
are responsible for $\mathrm{N}_{2} \mathrm{O}$ emission during wastewater treatment, including $\mathrm{AOB}$ denitrification, hydroxylamine oxidation and heterotrophic denitrification [5]. AOB denitrification was prominent under high $\mathrm{NO}_{2}-\mathrm{N}$ concentrations [6]. Especially, $\mathrm{N}_{2} \mathrm{O}$ emission was stimulated under low $\mathrm{DO}$, high $\mathrm{NO}_{2}-\mathrm{N}$ concentration and with the heterotrophic activity in the intermittent aeration process $[7,8]$. In the presence of heterotrophs, microbial competition among AOB, NOB and heterotrophs would be promoted, resulting in more $\mathrm{N}_{2} \mathrm{O}$ emission, which was highly dependent on the DO concentration [7]. Therefore, the selection of predominant microorganisms with the ability to reduce $\mathrm{N}_{2} \mathrm{O}$ was a key point to mitigate $\mathrm{N}_{2} \mathrm{O}$ emission. There was no consensus on what kind of nitrifiers in terms of $\mathrm{r} / \mathrm{K}$-strategist benefiting $\mathrm{N}_{2} \mathrm{O}$ mitigation. In a duckweed treatment ponds treating simulated stormwater, the growth of K-strategist (with a high substrate affinity and a low half saturation constant) may be responsible for low $\mathrm{N}_{2} \mathrm{O}$ emissions [9]. In contrast, $\mathrm{N}_{2} \mathrm{O}$ production was 25 times higher in completely stirred tank reactor (CSTR)-enriched biomass (K-strategist AOB) than in SBR-enriched biomass (r-strategist AOB) [10]. The mechanism behind this phenomenon needs to be further investigated.

SBR and CSTR have distinct regimes supplying wastewater for microorganisms and therefore may lead to diverse microbial community [10-12]. Due to the continuous organic supply pattern, system with the continuous feeding mode might benefit denitrifiers, especially for $\mathrm{N}_{2} \mathrm{O}$-reducing related denitrifiers, resulting in low $\mathrm{N}_{2} \mathrm{O}$ emission [11]. In addition, SBR and CSTR regimes support different predominant AOB (K-strategist and r-strategist with different growth rates or substrate affinity constants) exhibiting distinct biokinetic properties [12]. SBR can select r-strategist AOB, while CSTR can select K-strategist AOB. Halophilic and halotolerant Nitrosomonas lineage were more highly enriched in SBR, whereas Nitrosospira spp. in CSTR [10]. As a result, the $\mathrm{N}_{2} \mathrm{O}$ emission characteristics may be entirely different. K-strategists of Nitrosomonas oligtropha and Nitrosospira spp. had a high potential in $\mathrm{N}_{2} \mathrm{O}$ production at lower $\mathrm{NH}_{4}-\mathrm{N}$ concentrations [13]. Additionally, SBR with high substrate gradients during the reaction cycle, could lead to more $\mathrm{N}_{2} \mathrm{O}$ emissions compared to CSTR [14]. $\mathrm{N}_{2} \mathrm{O}$ production during denitrification could be controlled by altering $\mathrm{NO}_{2}-\mathrm{N}$ feeding strategy. Compared to pulse feeding, $\mathrm{N}_{2} \mathrm{O}$ emission from the step-wise feeding and continuous feeding reactors were reduced by 3.1-4.2 and 8.2-11.7 folds, respectively [15]. Hence, continuous feeding might be efficient to minimize $\mathrm{N}_{2} \mathrm{O}$ emission. Taken together, a big controversy is that SBR regime may support fast-growing $\mathrm{AOB}$ and therefore favor the nitrogen removal but with high $\mathrm{N}_{2} \mathrm{O}$ emission potential. The discrepancy under these two regimes in terms of $\mathrm{N}_{2} \mathrm{O}$ emission and nitrogen removal needs to be in-depth studied.

This study aimed to investigate nitrogen removal and $\mathrm{N}_{2} \mathrm{O}$ emission induced by microbial community from two types of intermittent aeration processes operated under high and low DO conditions. Nitrification and denitrification activities were examined under different DO concentrations and electron acceptors, respectively. Furthermore, microbial community diversity and abundance and their correlation with $\mathrm{N}_{2} \mathrm{O}$ emission were analyzed.

\section{Materials and Methods}

\subsection{SBR and CMR Systems}

Two 27-L continuous-flow multiple AO reactors were operated under high DO (CMR-H) and low DO conditions (CMR-L). The system consisted of seven sequential reaction tanks, including anaerobic (3 L), aerobic I (3 L), anoxic I (3 L), aerobic II (3 L), anoxic II (3 L), aerobic III (3 L) and settling tank (7 L). The anoxic tanks were mixed by mechanical stirrers. The sludge recirculation ratio and the internal recycling ratio were both $100 \%$. The DO concentration in the aerobic III tank was controlled at $1 \mathrm{mg} / \mathrm{L}$ in CMR-L and $2 \mathrm{mg} / \mathrm{L}$ in CMR-H.

Two 8-L SBRs were operated also under high DO (SBR-H) and low DO conditions (SBR-L). Both SBRs included four cycles per day and each cycle consisted of a 120-min anaerobic phase, a 120-min intermittent aeration phase with aerobic I (30 min), anoxic I (30 min), aerobic II (30 $\mathrm{min}$ ) and anoxic II (30 min), a 60-min aerobic phase (aerobic III) and a 60-min settling phase. During aerobic phases, DO concentrations was controlled at 1 $\mathrm{mg} / \mathrm{L}$ in SBR-L and $2 \mathrm{mg} / \mathrm{L}$ in SBR-H. In each cycle, $4 \mathrm{~L}$ of treated supernatant was discharged and $4 \mathrm{~L}$ of synthetic wastewater was pumped into the reactor by peristaltic pumps.

All reactors were inoculated with activated sludge taken from a domestic wastewater treatment plant in Shenzhen, China. Sludge retention time and hydraulic retention time were 15 $\mathrm{d}$ and $12 \mathrm{~h}$, respectively. All reactors were operated under room temperature $\left(24 \pm 0.5^{\circ} \mathrm{C}\right)$.

The synthetic wastewater consisted of $510 \mathrm{mg} / \mathrm{L}$ sodium acetate (NaAc), $153 \mathrm{mg} / \mathrm{L} \mathrm{NH}{ }_{4} \mathrm{Cl}, 14 \mathrm{mg} / \mathrm{L} \mathrm{CaCl} 2 \cdot 2 \mathrm{H}_{2} \mathrm{O}, 90 \mathrm{mg} / \mathrm{L}$ $\mathrm{MgSO}_{4} \cdot 7 \mathrm{H}_{2} \mathrm{O}, 46 \mathrm{mg} / \mathrm{L} \mathrm{Na}_{2} \mathrm{HPO}_{4}, 10 \mathrm{mg} / \mathrm{L}$ yeast extract, $100 \mathrm{mg} / \mathrm{L}$ $\mathrm{NaHCO}_{3}$ and $0.4 \mathrm{~mL} / \mathrm{L}$ trace elements. The composition of trace elements was according to Smolders et al. [16]. The synthetic wastewater contained around $400 \mathrm{mg} / \mathrm{L}$ of chemical oxygen demand (COD) and $40 \mathrm{mg} / \mathrm{L}$ of $\mathrm{NH}_{4}-\mathrm{N}$.

\subsection{Nitrifying Batch Experiments}

Nitrification batch experiments were conducted to examine nitrifying activities and $\mathrm{N}_{2} \mathrm{O}$ emission characteristics. The examined conditions included effects of DO concentrations (2.0 and $1.0 \mathrm{mg} / \mathrm{L}$ ) and the presence of heterotrophic activity.

800-mL activated sludge was taken from the aerobic III tank/phase in CMR or SBR systems, respectively. After settlement, supernatant was discarded and the activated sludge was resuspended with $800 \mathrm{~mL}$ synthetic wastewater without the addition of $\mathrm{NaAc}$ and $\mathrm{NH}_{4}-\mathrm{N}$. During each batch experiment, 800 $\mathrm{mL}$ of mixed liquor was divided into two parts and filled into batch reactors. The set $\mathrm{DO}$ concentrations in batch reactors were controlled by adjusting aeration rates of air and $\mathrm{N}_{2}$. For examining the effect of DO on the ammonia oxidation activity, $30 \mathrm{mg} / \mathrm{L}$ of $\mathrm{NH}_{4}-\mathrm{N}$ was dosed. For examining the effect of DO on nitrite oxidation activity, $20 \mathrm{mg} / \mathrm{L}$ of $\mathrm{NO}_{2}-\mathrm{N}$ was initially dosed. For examining the effect of DO with the presence of heterotrophic activity on ammonia oxidation activity, $30 \mathrm{mg} / \mathrm{L}$ of $\mathrm{NH}_{4}-\mathrm{N}$ and $500 \mathrm{mg} / \mathrm{L}$ of $\mathrm{NaAc}$ were applied. For examining the effect of DO with the presence of heterotrophic activity on nitrite oxidation activity, $20 \mathrm{mg} / \mathrm{L}$ of $\mathrm{NO}_{2}-\mathrm{N}$ and $500 \mathrm{mg} / \mathrm{L}$ of $\mathrm{NaAc}$ were applied. 
Each experiment was carried out in duplicate. During all batch experiments, gas and liquid samples were taken at intervals of 10 min to analyze concentrations of $\mathrm{N}_{2} \mathrm{O}$ in the gas phase and $\mathrm{NH}_{4}-\mathrm{N}, \mathrm{NO}_{2}-\mathrm{N}$ and $\mathrm{NO}_{3}-\mathrm{N}$ in the liquid phase. Suspended solids (SS) and volatile suspended solids (VSS) were measured before the beginning of each batch experiment. Liquid $\mathrm{N}_{2} \mathrm{O}$, DO concentrations and $\mathrm{pH}$ were measured on-line.

\subsection{Denitrifying Batch Experiments}

Denitrifying batch experiments were conducted to examine the activity of denitrifiers and $\mathrm{N}_{2} \mathrm{O}$ emission under conditions with electron acceptors of $\mathrm{NO}_{2}-\mathrm{N}$ and $\mathrm{NO}_{3}-\mathrm{N}$ and electron donors of $\mathrm{NaAc}$ and polyhydroxyalkanoates (PHAs), respectively.

For denitrification with PHAs, 800-mL activated sludge was taken from the anaerobic tank. Then, it was divided into two parts and filled into two batch reactors. After stripping with $\mathrm{N}_{2}$, batch experiments were started after the addition of $20 \mathrm{mg} / \mathrm{L}$ of $\mathrm{NO}_{2}-\mathrm{N}$ or $30 \mathrm{mg} / \mathrm{L}$ of $\mathrm{NO}_{3}-\mathrm{N}$, respectively, to investigate the effect of electron acceptor on the denitrifying activity and $\mathrm{N}_{2} \mathrm{O}$ emission.

For denitrification with NaAc, 800-mL activated sludge was taken from the aerobic III tank/phase in CMR and SBR systems. After settlement, supernatant was discarded and the activated sludge was resuspended with $800 \mathrm{~mL}$ synthetic wastewater without the addition of NaAc. $800 \mathrm{~mL}$ of mixed liquor was divided into two parts and filled into two batch reactors. After stripping with $\mathrm{N}_{2}$, batch experiments were started with the addition of $20 \mathrm{mg} / \mathrm{L}$ of $\mathrm{NO}_{2}-\mathrm{N}$ and $500 \mathrm{mg} / \mathrm{L}$ of $\mathrm{NaAc}$, or $30 \mathrm{mg} / \mathrm{L}$ of $\mathrm{NO}_{3}-\mathrm{N}$ and $500 \mathrm{mg} / \mathrm{L}$ of $\mathrm{NaAc}$, respectively, to investigate the effect of electron acceptor on the denitrifying activity and $\mathrm{N}_{2} \mathrm{O}$ emission.

Each experiment was carried out in duplicate. During all batch experiments, gas and liquid samples were taken at intervals of 10 min to analyze concentrations of $\mathrm{N}_{2} \mathrm{O}$ in the gas phase and $\mathrm{NO}_{2}-\mathrm{N}$ and $\mathrm{NO}_{3}-\mathrm{N}$ in the liquid phase. SS and VSS were measured before the beginning of the batch experiment. Liquid $\mathrm{N}_{2} \mathrm{O}$, DO concentrations and $\mathrm{pH}$ were measured on-line.

\subsection{Analytical Methods}

$\mathrm{NH}_{4}-\mathrm{N}, \mathrm{NO}_{3}-\mathrm{N}, \mathrm{NO}_{2}-\mathrm{N}$, SS and VSS were measured according to standard methods [17]. DO and $\mathrm{pH}$ were measured by a portable DO meter (Flexi, HACH, USA) and a $\mathrm{pH}$ meter (pH 30d, HACH, USA), respectively. $\mathrm{N}_{2} \mathrm{O}$ was tested by a gas chromatograph (GC-9720, Fuli, China) with an electron capture detector and a HP-PLOT/Q column (J\&W GC Columns, Agilent Technologies, USA) according to Wang et al. [7]. The $\mathrm{N}_{2} \mathrm{O}$ emission factor was calculated according to Kimochi et al. [18]. The efficiency of SND was calculated based on Wang et al. [7].

DNA was extracted from activated sludge using a Fast DNA Spin Kit (Laboratories, Inc., Carlsbad, USA) according to the manufacturer's instruction. The DNA sample was amplified by polymerase chain reaction in the V4 region of the target fragment 16S rRNA gene, and analyzed by high-throughput sequencing using the Illumina Miseq platform. The primers were $515 \mathrm{~F}$ and $806 \mathrm{R}$ [19]. After screening, species classification of the representative spliced sequences for each OTU was performed using the Qiime software. Results were classified to the phylum, class, order, family and genus levels. The taxonomies for 16S rRNA microbial communities had been deposited in the NCBI BioProject database with the accession ID of PRJNA342302.

\section{Results and Discussion}

\subsection{Performance of SBR and CMR Reactors}

Table 1 shows the performance of SBR and CMR systems under steady state. Under steady state, the SS/VSS in SBR-L, SBR-H, CMR-L and CMR-H were 3.50/2.81, 3.88/3.12, 3.34/2.68 and $3.44 / 2.75 \mathrm{~g} / \mathrm{L}$. Four systems achieved desirable removal efficiencies for $\mathrm{NH}_{4}-\mathrm{N}$ (99.3-99.7\%). CMR-L achieved the best effluent quality for TIN, with the $\mathrm{NO}_{3}-\mathrm{N}$ concentration of $3.55 \mathrm{mg} / \mathrm{L}$ and $\mathrm{NH}_{4}-\mathrm{N}$ of $0.28 \mathrm{mg} / \mathrm{L}$, and the corresponding removal efficiencies of TIN and $\mathrm{NH}_{4}-\mathrm{N}$ were $91.5 \%$ and $99.3 \%$, respectively. In contrast, the highest effluent $\mathrm{NO}_{3}-\mathrm{N}$ concentration of 10.46 $\mathrm{mg} / \mathrm{L}$ was obtained in SBR-H, with the TIN removal efficiency of $75.2 \%$. TIN removal efficiencies under low DO conditions were obviously higher than under high DO conditions, which might be due to high SND efficiency under low DO conditions

Table 1. Performance under Steady State in SBR and CMR Systems

\begin{tabular}{|c|c|c|c|c|c|}
\hline & & SBR-L & SBR-H & CMR-L & CMR-H \\
\hline \multirow{3}{*}{ Influent (mg/L) } & $\mathrm{NH}_{4}-\mathrm{N}$ & \multicolumn{4}{|c|}{$43 \pm 2.0$} \\
\hline & $\mathrm{NO}_{3}-\mathrm{N}$ & \multicolumn{4}{|c|}{$2.5 \pm 1.65$} \\
\hline & $\mathrm{PO}_{4}-\mathrm{P}$ & \multicolumn{4}{|c|}{$10 \pm 0.38$} \\
\hline \multirow{4}{*}{ Effluent (mg/L) } & $\mathrm{NH}_{4}-\mathrm{N}$ & $0.13 \pm 0.12$ & $0.17 \pm 0.13$ & $0.28 \pm 0.51$ & $0.18 \pm 0.44$ \\
\hline & $\mathrm{NO}_{2}-\mathrm{N}$ & $0.12 \pm 0.03$ & $0.04 \pm 0.07$ & $0.0 \pm 0.007$ & $0.0 \pm 0.01$ \\
\hline & $\mathrm{NO}_{3}-\mathrm{N}$ & $7.73 \pm 0.09$ & $10.46 \pm 0.20$ & $3.55 \pm 2.12$ & $8.03 \pm 1.30$ \\
\hline & $\mathrm{PO}_{4}-\mathrm{P}$ & $0.21 \pm 0.12$ & $0.08 \pm 0.10$ & $0.5 \pm 1.21$ & $0.05 \pm 0.12$ \\
\hline \multirow{3}{*}{ Removal efficiency (\%) } & $\mathrm{NH}_{4}-\mathrm{N}$ & 99.7 & 99.6 & 99.3 & 99.6 \\
\hline & TIN & 81.4 & 75.2 & 91.5 & 82.0 \\
\hline & $\mathrm{PO}_{4}-\mathrm{P}$ & 97.9 & 99.2 & 95.0 & 99.5 \\
\hline
\end{tabular}


[20]. In addition, TIN removal efficiencies under CMR conditions were higher than that under SBR conditions. Hence, CMR systems with a low DO condition benefited nitrogen removal. Chen et al. [21] also obtained that enhanced nitrogen removal was achieved in a continuous-flow intermittent aeration process with low DO (0.3-1.0 mg/L), with the TN removal efficiency up to $94.9 \%$. While in a continuous plug-flow step feed process with the intermittent aeration (DO $=1.5-2.0 \mathrm{mg} / \mathrm{L}$ ), $\mathrm{TN}$ removal efficiency of $86 \%$ was achieved [3].

\subsection{Nitrifying Activity and $\mathrm{N}_{2} \mathrm{O}$ Emission}

Nitrifying activity was tested under different DO concentrations and in the presence of organic carbon, with results shown in Table 2.

With increasing DO concentrations from $1.0 \mathrm{mg} / \mathrm{L}$ to $2.0 \mathrm{mg} / \mathrm{L}$, activities of AOB increased, while that of NOB was less affected. Correspondingly, the ratio between nitrite oxidizing rate $\left(\mathrm{r}_{\mathrm{NOB}}\right)$ and ammonium oxidizing rate $\left(\mathrm{r}_{\mathrm{AOB}}\right)$ decreased from 1.06-1.37 to $0.74-1.08$. Importantly, in the presence of organic carbon, NOB activity was significantly suppressed, independent of DO concentrations. The $\mathrm{r}_{\mathrm{NOB}} / \mathrm{r}_{\mathrm{AOB}}$ ratio markedly reduced from 1.06-1.37 to $0.47-1.21$ under DO of $1 \mathrm{mg} / \mathrm{L}$ and from $0.74-1.08$ to $0.52-0.98$ under $\mathrm{DO}$ of $2 \mathrm{mg} / \mathrm{L}$. The balance between AOB and NOB could be destroyed in the presence of organic carbon, which might result in $\mathrm{NO}_{2}-\mathrm{N}$ accumulation in the intermittent aeration process [2]. With organics, competition for oxygen between heterotrophs and nitrifiers would be promoted, with the suppressed nitrifying activity [22]. Furthermore, the suppression of NOB in SBR systems was more remarkable (with relatively low $\mathrm{r}_{\mathrm{NOB}} / \mathrm{r}_{\mathrm{AOB}}$ ratio) in comparison with CMR systems, especially in the presence of organics. The result was consistent with Wang et al. [2], who demonstrated that the $\mathrm{r}_{\mathrm{NOB}} / \mathrm{r}_{\mathrm{AOB}}$ ratio was 0.32 in the multiple AO SBR process, which was lower than 0.98 of the AO SBR process [2]. In the presence of organics, AOB activity was inhibited in sequencing batch biofilm reactors, where the $\mathrm{r}_{\mathrm{NOB}} / \mathrm{r}_{\mathrm{AOB}}$ ratio was $0.21-1.08$ without and $0.25-1.25$ with the addition of organics [23].

As shown in Fig. 1(a), $\mathrm{N}_{2} \mathrm{O}$ emission was triggered during ammonia oxidation in the presence of organic carbon. Herein, $\mathrm{N}_{2} \mathrm{O}$ emission factors ranged from $0.21-1.18 \%$ in the absence of organic carbon, which were significantly lower than those with the presence of organic carbon (2.47-11.39\%). Particularly, in the absence of organic carbon, SBR systems possessed higher $\mathrm{N}_{2} \mathrm{O}$ emission potential (with $\mathrm{N}_{2} \mathrm{O}$ emission factors of 0.73-1.18\%) compared to CMR systems (with $\mathrm{N}_{2} \mathrm{O}$ emission factors of $0.21-0.68 \%$ ). In the presence of organic carbon, however, more $\mathrm{N}_{2} \mathrm{O}$ emission occurred in CMR systems compared to SBR systems under the DO of $2 \mathrm{mg} / \mathrm{L}$. SBR-L and CMR-L had higher $\mathrm{N}_{2} \mathrm{O}$ emission potential (with $10.24 \%$ and $8.89 \%$ of $\mathrm{N}_{2} \mathrm{O}$ emission factor) comparing to SBR-H and CMR-H (with $6.60 \%$ and $2.47 \%$ of $\mathrm{N}_{2} \mathrm{O}$ emission factor) under DO of $1 \mathrm{mg} / \mathrm{L}$. From Fig. 1(d), high SND efficiency under low DO conditions might be the reason responsible for this phenomenon. $\mathrm{N}_{2} \mathrm{O}$ emission was positively correlated with $\mathrm{r}_{\mathrm{NH} 4-\mathrm{N}}$. Besides, low DO concentrations (less than $0.2 \mathrm{mg} / \mathrm{L}$ ) facilitated $\mathrm{N}_{2} \mathrm{O}$ generation from AOB denitrification [24]. $\mathrm{N}_{2} \mathrm{O}$ from AOB denitrification pathway decreased as DO concentration increased from 0.35 to $3.5 \mathrm{mg} / \mathrm{L}$ [6]. Interestingly, $\mathrm{SBR}_{\mathrm{L}}$ and $\mathrm{CMR}_{\mathrm{L}}$ possessed the higher $\mathrm{N}_{2} \mathrm{O}$ emission factors comparing to $\mathrm{SBR}_{\mathrm{H}}$ and $\mathrm{CMR}_{\mathrm{H}}$ when the oxygen concentration was limited (1 mg/L), suggesting that oxygen was the determining factor affecting $\mathrm{N}_{2} \mathrm{O}$ emission. However, CMR systems exhibited high $\mathrm{N}_{2} \mathrm{O}$ emission when oxygen concentration was not limited $(2 \mathrm{mg} / \mathrm{L})$. The supply regime might be the decisive factor under this condition. Besides, the $\mathrm{N}_{2} \mathrm{O}$ emission factors observed under this condition were higher than that under DO of $1 \mathrm{mg} / \mathrm{L}$, which further demonstrated that CMR affected the $\mathrm{N}_{2} \mathrm{O}$ emission intrinsically rather than DO. This was consisted with the result that $\mathrm{N}_{2} \mathrm{O}$ emission during nitrification correlated with $\mathrm{r}_{\mathrm{NH} 4-\mathrm{N}}$ (Fig. $1(\mathrm{~d})$ ) and the lower $\mathrm{r}_{\mathrm{NH} 4-\mathrm{N}}$ in CMR. The microorganisms' selection by CMR system might be the underlying reason for $\mathrm{N}_{2} \mathrm{O}$ emission, which was in line with Terada et al. [10] that CSTR predominantly enriched slow-growing (K-strategist) AOB, contributing to more $\mathrm{N}_{2} \mathrm{O}$ production.

In the presence of organics, heterotrophic activities affected $\mathrm{N}_{2} \mathrm{O}$ emission during nitrification significantly. The $\mathrm{N}_{2} \mathrm{O}$ emission obtained from this study $(2.47 \%-11.39 \%)$ was within the $0.70 \%-14.50 \%$ from Shen et al. [25] and obviously lower than $15 \%$ (the ratio between the $\mathrm{N}_{2} \mathrm{O}$ production rate and the ammonia oxidation rate) from Wunderlin et al. [5]. Presumably,

Table 2. Nitrifying Activity under Different DO Concentrations

\begin{tabular}{|c|c|c|c|c|c|c|}
\hline & \multicolumn{3}{|c|}{$D O=1 \mathrm{mg} / \mathrm{L}$} & \multicolumn{3}{|c|}{ DO $=2 \mathrm{mg} / \mathrm{L}$} \\
\hline & $\mathbf{r}_{\mathrm{AOB}}$ & $\mathbf{r}_{\mathrm{NOB}}$ & $\mathbf{r}_{\mathrm{NOB}} / \mathbf{r}_{\mathrm{AOB}}$ & $\mathbf{r}_{\mathrm{AOB}}$ & $\mathbf{r}_{\mathrm{NOB}}$ & $\mathbf{r}_{\mathrm{NOB}} / \mathbf{r}_{\mathrm{AOB}}$ \\
\hline SBR-L & -6.65 & -7.30 & 1.10 & -6.46 & -6.98 & 1.08 \\
\hline SBR-H & -4.84 & -5.19 & 1.07 & -6.85 & -5.10 & 0.74 \\
\hline CMR-L & -4.51 & -4.80 & 1.06 & -5.09 & -4.89 & 0.96 \\
\hline CMR-H & -3.91 & -5.34 & 1.37 & -5.12 & -5.45 & 1.06 \\
\hline SBR-L with acetate & -6.44 & -3.00 & 0.47 & -7.92 & -4.10 & 0.52 \\
\hline SBR-H with acetate & -5.90 & -3.50 & 0.59 & -7.70 & -3.40 & 0.44 \\
\hline CMR-L with acetate & -5.92 & -3.96 & 0.67 & -5.83 & -4.15 & 0.71 \\
\hline CMR-H with acetate & -5.62 & -6.78 & 1.21 & -6.03 & -5.92 & 0.98 \\
\hline
\end{tabular}

$\mathrm{r}_{\mathrm{AOB}}$ and $\mathrm{r}_{\mathrm{NOB}}$ referred to the ammonia oxidation rate $\left(\mathrm{r}_{\mathrm{NH4}-\mathrm{N}}\right)$ and the nitrite oxidation rate ( $\left.\mathrm{r}_{\mathrm{NO} 2-\mathrm{N}}\right)$, respectively. 

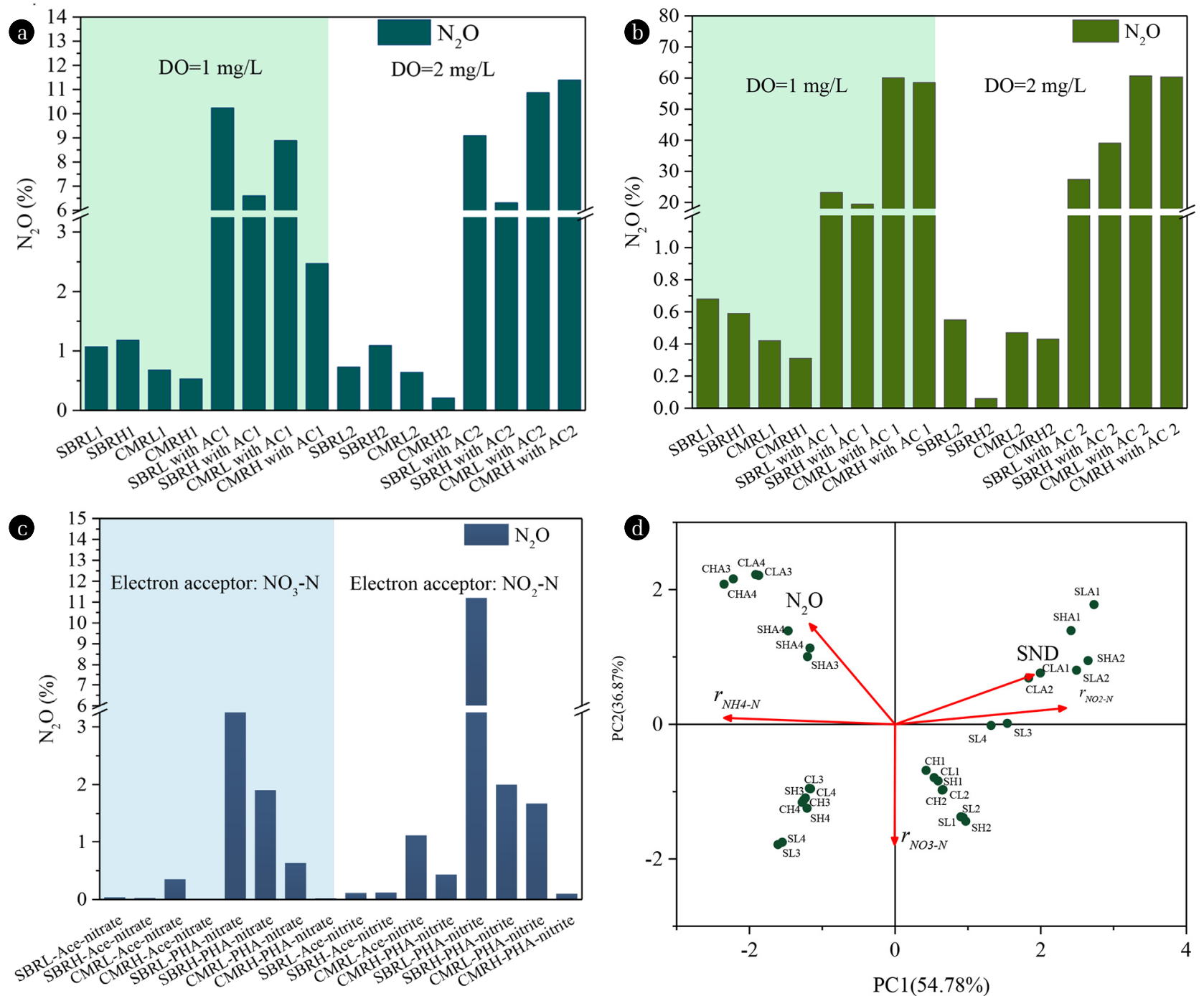

Fig. 1. $\mathrm{N}_{2} \mathrm{O}$ emission characteristics during ammonia oxidation process (a), nitrite oxidation process (b), denitrification (c), PCA ordination diagram based on nitrification batch experiments (d). CL, CH, SH, and SL represent CMR-L, CMR-H, SBR-H and SBR-L, respectively. A represents addition of acetate. $r_{\mathrm{NH}-\mathrm{N}}, \mathrm{r}_{\mathrm{NO} 2-\mathrm{N}}$ and $\mathrm{r}_{\mathrm{NO} 3-\mathrm{N}}$ represent $\mathrm{NH}_{4}-\mathrm{N}$ oxidation rate, $\mathrm{NO}_{2}-\mathrm{N}$ oxidation rate and $\mathrm{NO}_{3}-\mathrm{N}$ production rate, respectively. Number 1 and 2 represent ammonia oxidation batch experiment under low DO and high DO conditions, respectively. Number 3 and 4 represent nitrite oxidation batch experiment under low DO and high DO conditions, respectively.

heterotrophic activities might decrease the DO availability for AOB. Therefore, AOB denitrification pathway would be enhanced.

For $\mathrm{N}_{2} \mathrm{O}$ emission during $\mathrm{NO}_{2}-\mathrm{N}$ oxidation (Fig. 1(b)), $0.06 \%$ - $0.68 \%$ of $\mathrm{NO}_{2}-\mathrm{N}$ was emitted as $\mathrm{N}_{2} \mathrm{O}$ in the absence of organic carbon independent of DO concentrations, whereas $\mathrm{N}_{2} \mathrm{O}$ emission was stimulated in the presence of organic carbon, with $\mathrm{N}_{2} \mathrm{O}$ emission factors of $23.2 \%-60.7 \%$. Besides, $\mathrm{N}_{2} \mathrm{O}$ emission under $\mathrm{DO}=2.0 \mathrm{mg} / \mathrm{L}$ conditions in all four systems was higher than that under DO $=1.0 \mathrm{mg} / \mathrm{L}$, which was likely a result of activity inhibition of Nos by the high DO concentrations [15]. CMR systems possessed more $\mathrm{N}_{2} \mathrm{O}$ emission capacities (with $58.54 \%$ - $60.70 \%$ of $\mathrm{N}_{2} \mathrm{O}$ emission factors) independent of organic carbon compared to SBR systems (with $19.45 \%$ - 39.08\% of $\mathrm{N}_{2} \mathrm{O}$ emission factor). It's worth mentioning that higher $\mathrm{N}_{2} \mathrm{O}$ emission under $\mathrm{DO}=2.0 \mathrm{mg} / \mathrm{L}$ might be triggered by air stripping. Under anoxic or low DO conditions, $\mathrm{N}_{2} \mathrm{O}$ produced could be reduced in addition to emitted. However, under stripping conditions, $\mathrm{N}_{2} \mathrm{O}$ emission was triggered significantly and $\mathrm{N}_{2} \mathrm{O}$ emission amount was increased by 6 -fold compared to that without stripping [26].

Compared with ammonia oxidation, $\mathrm{N}_{2} \mathrm{O}$ emission from $\mathrm{NO}_{2}-\mathrm{N}$ oxidation might be from heterotrophic denitrification as no $\mathrm{NO}_{3}-\mathrm{N}$ production occurred. Under the $1.1 \mathrm{mg} \mathrm{O} / \mathrm{L}$ condition, heterotrophic denitrification could be responsible for $40 \%$ of the $\mathrm{N}_{2} \mathrm{O}$ production based on Tallec et al. [27]. $\mathrm{NO}_{2}-\mathrm{N}$ heterotrophic denitrification was responsible for $60 \%$ of $\mathrm{N}_{2} \mathrm{O}$ production during partial nitrification [28]. The present study 
demonstrated that heterotrophic denitrification dominated the $\mathrm{N}_{2} \mathrm{O}$ emission during $\mathrm{NO}_{2}-\mathrm{N}$ oxidation because the addition of organics. Based on Wang et al. [29], the organic utilization efficiency of heterotrophic denitrifiers might be a regulator for $\mathrm{N}_{2} \mathrm{O}$ emission. Thus, the high $\mathrm{N}_{2} \mathrm{O}$ emission capacity in CMR systems was attributed to less abundant heterotrophs reducing $\mathrm{N}_{2} \mathrm{O}$ to $\mathrm{N}_{2}$.

\subsection{Denitrifying Activity and $\mathrm{N}_{2} \mathrm{O}$ Emission}

Denitrifying activities were examined with $\mathrm{NO}_{2}-\mathrm{N}$ or $\mathrm{NO}_{3}-\mathrm{N}$ as the electron acceptor and acetate or PHA as the carbon source, with results shown in Table 3. SBRs had a higher denitrifying rate when $\mathrm{NO}_{3}-\mathrm{N}$ was used as the electron acceptor, independent of carbon sources. In contrast, a higher denitrifying rate was observed in SBR systems with $\mathrm{NO}_{2}-\mathrm{N}$ and acetate as the electron acceptor and donor, respectively. Overall, SBRs had a higher denitrifying rate regardless of carbon types and electron acceptors. The possible reason could be due to that SBR enriched more abundant denitrifiers. Specially, higher denitrifying rates with $\mathrm{NO}_{2}-\mathrm{N}$ were observed in CMR-L with acetate as the organic carbon, meaning that denitrifiers enriched in CMR, especially under low DO conditions, were liable to utilize $\mathrm{NO}_{2}-\mathrm{N}$ as the electron acceptor. SBR (especially SBR-H) facilitated denitrification with PHAs as electron donor due to the higher storage capacity of PHAs under pulse feeding conditions compared to continuous feeding conditions [30].

$\mathrm{N}_{2} \mathrm{O}$ emission was stimulated in SBRs with PHAs as the electron donor. As shown in Fig. 1(c), SBR-L emitted more $\mathrm{N}_{2} \mathrm{O}$ when using PHAs, especially with $\mathrm{NO}_{2}-\mathrm{N}$ as the electron acceptor. In addition, SBR with low DO concentrations were prone to emit more $\mathrm{N}_{2} \mathrm{O}$, which was likely a result of less abundant of

Table 3. Denitrifying Activity under Different Electron Acceptor

\begin{tabular}{llcc}
\hline & & $\mathbf{r}_{\mathrm{NO}-\mathbf{N}}$ & $\mathbf{r}_{\mathrm{NO}-\mathrm{N}}$ \\
\cline { 3 - 4 } & & $\mathbf{E A}: \mathbf{N O}_{2}-\mathbf{N}$ & $\mathbf{E A}: \mathbf{N O}_{3}-\mathbf{N}$ \\
\hline \multirow{2}{*}{ External carbon } & SBR-L & -11.31 & -13.96 \\
source (Ace) & SBR-H & -10.26 & -20.84 \\
& CMR-L & -13.39 & -12.58 \\
& CMR-H & -12.81 & -12.25 \\
Internal carbon & SBR-L & -4.88 & -5.39 \\
source (PHAs) & SBR-H & -5.25 & -11.13 \\
& CMR-L & -3.29 & -4.25 \\
& CMR-H & -1.41 & -1.15 \\
\hline
\end{tabular}

Ace: acetate; EA: electron acceptor; $\mathrm{r}_{\mathrm{NO} 2-\mathrm{N}}$ and $\mathrm{r}_{\mathrm{NO} 3-\mathrm{N}}$ with unit of $\mathrm{mg} \mathrm{N} /(\mathrm{g}$ VSS$\cdot \mathrm{h})$.
$\mathrm{N}_{2} \mathrm{O}$ reduction related denitrifier [11]. SBR owned less abundant $\mathrm{N}_{2} \mathrm{O}$-reducing denitrifiers compared to continuous feeding systems. The PHAs-type denitrification (with $\mathrm{NO}_{2}-\mathrm{N}$ ) caused more $\mathrm{N}_{2} \mathrm{O}$ emission, likely due to the slow degradation rate of PHAs inducing the competition for electrons between denitrifying enzymes [23, 31]. Denitrifiers of IASBR preferred to utilize PHAs for denitrification [2]. As a result, more $\mathrm{N}_{2} \mathrm{O}$ emission was observed for denitrifiers in SBR.

$\mathrm{NO}_{2}-\mathrm{N}$ triggered the $\mathrm{N}_{2} \mathrm{O}$ emission especially for SBR-L and CMR-L. Lemaire et al. [32] also confirmed that the addition of $\mathrm{NO}_{2}-\mathrm{N}$ led to five times higher net $\mathrm{N}_{2} \mathrm{O}$ production rate compared to the addition of $\mathrm{NO}_{3}-\mathrm{N}$. Besides, the difference in the rate of $\mathrm{NO}_{3}-\mathrm{N}$ and $\mathrm{NO}_{2}-\mathrm{N}$ reduction could also lead to the accumulation of $\mathrm{N}_{2} \mathrm{O}$. Free nitrous acid (FNA) might be the true inhibitor because FNA could bind to the active sites of copper-contained $\mathrm{N}_{2} \mathrm{O}$ reductase, resulting in the inhibition to the $\mathrm{N}_{2} \mathrm{O}$ reduction. Fifty percent inhibition concentration of FNA was 0.0007-0.001 mg $\mathrm{HNO}_{2}-\mathrm{N} / \mathrm{L}$, equivalent to approximately 3-4 $\mathrm{mg} \mathrm{NO}_{2}-\mathrm{N} / \mathrm{L}$ at $\mathrm{pH} 7$ [33]. For denitrifying polyphosphate accumulating organisms (DNPAOs), denitrifying $\mathrm{NO}_{2}-\mathrm{N}$ to $\mathrm{N}_{2} \mathrm{O}$ was enhanced as soon as $\mathrm{NO}_{2}-\mathrm{N}$ increased to above $1 \mathrm{mg} / \mathrm{L}$ [34]. Batch experiments showed that four systems enriched DNPAOs because $\mathrm{NO}_{2}-\mathrm{N}$ or $\mathrm{NO}_{3}-\mathrm{N}$ and $\mathrm{PO}_{4}-\mathrm{P}$ could be reduced simultaneously (data not shown). Presumably, DNPAOs might be better enriched under low DO conditions (SBR-L and CMR-L), leading to more $\mathrm{N}_{2} \mathrm{O}$ emission.

\subsection{Microbial Community Diversity and Abundance in SBR and CMR Reactors}

Table 4 depicts the microbial community abundance (Top 30) and diversity in four reactors. CMR-L had the highest microbial diversity, whereas SBR-H had the lowest diversity. In addition, from Figs. 2(a) and 2(b), 7.7\% and 15.8\% of species were the same among CMR and SBR conditions, respectively, indicating that SBR could maintain more species from the seed. $34.1 \%$ and $42.3 \%$ of species were common between CMR-H and CMR-L and between SBR-H and SBR-L, respectively. Noted that 813 and 801 unique species were enriched in CMR-L and CMR-H, while 599 and 560 species were enriched in SBR-L and SBR-H, suggesting that low DO and CMR conditions offered more favorable environment for microbial diversity. CMR systems could supply adequate nutrient supporting more organisms' growth, resulting in diverse microbial community [11].

Detailed microbial community abundance was investigated at the genus level (Fig. 2(c)). There were significant distinctions

Table 4. Microbial Population Abundance and Diversity

\begin{tabular}{cccccc}
\hline & Chao1 & Observed species & PD whole tree & Shannon & Simpson \\
\hline SBR-L & $3,580.510$ & 2,044 & 135 & 7.768 & 0.9753 \\
SBR-H & $3,580.500$ & 1,995 & 128 & 7.614 & 0.9749 \\
CMR-L & $3,740.736$ & 2,150 & 136 & 7.947 & 0.9782 \\
CMR-H & $3,522.857$ & 2,097 & 131 & 7.721 & 0.9737 \\
\hline
\end{tabular}


between the seed and the acclimated sludge in CMR reactors, however, only slight shifts in the distribution of genus was observed between the seed and the SBR sludge. In CMRs, the major genera in the seed were Dechloromonas (3.99\%), Zoogloea (4.43\%), Nitrospira (1.74\%), Caldilinea (0.82\%), Geothrix (0.81\%), Dok59 (0.55\%), Candidatus Accumulibacter (0.58\%) and Turneriella (0.61\%). Other minor genera included Prosthecobacter $(0.32 \%)$, Bdellovibrio (0.29\%), Thermomonas (0.49\%), Z-35 (0.34\%) and Gemmata (0.33\%). The dominating genera in CMR-H and CMR-L were Candidatus Accumulibacter $(9.76 \%$ and 11.26\%), Dechloromonas (5.03\% and 5.61\%) and Dok59 (1.73\% and 5.76\%), followed by Prosthecobacter (1.69\% and 1.14\%), Bdellovibrio (1.32\% and 1.43\%), Zoogloea (0.72\% and $0.63 \%)$ and Nitrospira $(0.66 \%$ and $1.36 \%)$. As for microorganisms in SBRs, Candidatus Aocumulibacter (2.93\%), Dechloromonas (1.41\%), Zoogloea (1.47\%), Prosthecobacter (1.92) and Thauera (1.23\%) were the major genera in the seed. Whereas Candidatus Accumulibacter (10.50\% and 12.74\%), Dechloromonas (10.29\% and 3.10\%), Dok59 (0.70\% and 1.17\%), Zoogloea $(1.66 \%$ and 1.18\%), Nitrospira (2.99\% and 1.81\%) and Bdellovibrio $(1.03 \%$ and $0.75 \%$ dominated in SBR-H and SBR-L. Candidatus Accumulibacter and Dechloromonas were the most abundant genera in all four reactors, which were polyphosphate accumulating organisms [35] or DNPAOs [36]. Dechloromonas survived in SBR-H, which was contrary to Liang et al. [11] that Dechloromonas adapted well to the continuous feeding system, which could be due to the enhancement of denitrifiers with PHAs in SBRs [2]. As a bacterial predator, Bdellovibrio could significantly shift the species composition in wastewater treatment systems, and might disturb the operational performance [37]. Prosthecobacter, Zoogloea, Thauera and Dechloromonas genera were commonly genera distributed in wastewater treatments plants [38, 39]. Prosthecobacter was thriving in $\mathrm{CMR}$, which belongs to oligotrophic heterotrophs enriched in low-nutrient environments [40].

Nitrosomonadaceae family and Nitrospira genus were responsible for $\mathrm{NH}_{4}-\mathrm{N}$ oxidation and $\mathrm{NO}_{2}-\mathrm{N}$ oxidation, respectively. The abundances of Nitrosomonadaceae family and Nitrospira genus in SBRs $(2.99 \%$ in SBR-H and $1.81 \%$ in SBR-L) were obviously higher than in CMRs (0.66\% in CMR-H and $1.38 \%$ in CMR-L) (Fig. 2(d)). Compared to the seed (CMR-DAY0 and SBR-DAY0), different shifts were observed for Nitrosomonadaceae family and Nitrospira genus in SBRs and CMRs. These two nitrifiers could be well maintained in SBRs rather than in CMRs. This observation was consistent with Liang et al. [11] that abundant AOB (Nitrosomonadales) and NOB (Nitrospira) were confirmed in batch feeding systems in comparison with continuous feeding systems. Nitrospira, possessing a low maximum specific growth rate, was a K-strategist that could be well-adapted to low substrate concentrations [41]. Park and Noguera [42] suggested that Nitrospira community had a dynamic change under different DO conditions. Kim and Kim [12] concluded that Nitrospira genus was preferring to live in continuous reactors comparing to SBRs. Therefore, the different composition of these nitrifying genus (probably r-strategist in SBRs and K-strategist in CMRs) enriched in different feeding patterns and DO concentrations might result in different nitrifying activity and $\mathrm{N}_{2} \mathrm{O}$ emission characteristics. Nitrosomonas europaea within the
Nitrosomonadales family, harbored nir (encoding nitrite reductase) and nor (encoding nitric reductase) genes while lack of nosZ (encoding nitrous oxide reductase) [43], was a source of $\mathrm{N}_{2} \mathrm{O}$ production. Some species within Nitrospira genus including Candidatus Nitrospira inopinata, Candidatus Nitrospira nitrosa and Candidatus Nitrospira nitrificans are known as Comammox that oxidize $\mathrm{NH}_{4}-\mathrm{N}$ to $\mathrm{NO}_{3}-\mathrm{N}$. However, data about the above species was absent. Hence, further researches are needed to evaluate their contributions on nitrogen conversion. In addition, based on the 16S rRNA result, ammonia oxidizing archaea of Candidatus Nitrososphaera within Crenarchaeota pylum were detected in all four reactors, with abundance of $0 \%-0.016 \%$. Their contributions in nitrogen need to be further evaluated.

Diverse denitrifiers including Dechloromonas, Zoogloea, Thauera, Comamonas, Methyloversatilis, Flavobacterium and Pseudomonas were obtained (Fig. 2(e)). Total abundance of these potential denitrifiers was $9.85 \%, 16.05 \%, 18.09 \%, 8.03 \%, 23.34 \%$ and $17.74 \%$ in seed sludge of CMR (CMR-DAY0), CMR-H, CMR-L, seed sludge of SBR (SBR-DAY0), SBR-H and SBR-L (Fig. 2(d)). Relative high abundances were observed in SBR-H and CMR-L. This observation could be an explanation about high denitrifying activity in SBR-H and CMR-L. Denitrifiers enriched in CMR might prefer to utilize $\mathrm{NO}_{2}-\mathrm{N}$ as the electron acceptor, whereas prefer to $\mathrm{NO}_{3}-\mathrm{N}$ in SBRs, indicating diverse microbial denitrifiers enriched. Particularly, Methyloversatilis spp. was reported as incomplete denitrifiers (reducing nitrate or nitrite to nitrogen oxide intermediates instead of $\mathrm{N}_{2}$ ), and Pseudomonas, Thauera and Burkholderia were incomplete nitrite reducers (capable of reducing nitrite to $\mathrm{N}_{2} \mathrm{O}$ intermediates harbor cd1-type nitrite reductase) [44, 45]. Dechloromonas, Comamonas and Flavobacterium were complete denitrifiers [46-48]. Dechloromonas carried both nirS (encoding nitrite reductase) and nosZ genes [46]. Flavobacterium enriched in biofiltration systems was nosZ-containing bacterial genera [48]. Some members of Zoogloea could utilize glucose and sodium acetates to remove nitrate [49]. Strand et al. [50] reported that one Zoogloea genus could reduce $\mathrm{NO}_{3}-\mathrm{N}$ at the $\mathrm{DO}$ concentration up to 8 $\mathrm{mg} / \mathrm{L}$. Thauera was dominant in IASBR treating digested piggery wastewater [51]. Although Thauera was found to be the nosZ owner in an intermittent aeration process [8], some members of Thauera was found to be a partial denitrifier that produces $\mathrm{N}_{2} \mathrm{O}$ as the end-product [43].

Candidatus Accumulibacter, which was reported as DNPAOs, proliferated especially in CMR-L (11.26\%) and SBR-L (12.74\%). These bacteria might be partly responsible for $\mathrm{N}_{2} \mathrm{O}$ emission during denitrification. This might explain why $\mathrm{N}_{2} \mathrm{O}$ emission was stimulated during $\mathrm{NO}_{2}-\mathrm{N}$ denitrification. For $\mathrm{N}_{2} \mathrm{O}$ emission related denitrifying genera, Methyloversatilis, Thauera, Burkholderia and Pseudomonas, accounted for $0.44 \%$ in $\mathrm{CMR}-\mathrm{H}, 0.32 \%$ in CMR-L, $0.61 \%$ in SBR-H and $0.41 \%$ in SBR-L. In contrast, Dechloromonas, Comamonas and Flavobacterium, which might be $\mathrm{N}_{2} \mathrm{O}$ reducers, accounted for $5.16 \%$ in CMR-H, $5.99 \%$ in CMR-L, $10.64 \%$ in SBR-H and 3.45\% in SBR-L. The ratios between $\mathrm{N}_{2} \mathrm{O}$ producers and reducers were $0.09,0.05,0.06$ and 0.12 in CMR-H, CMR-L, SBR-H and SBR-L, respectively. The lowest abundance of $\mathrm{N}_{2} \mathrm{O}$-reducing microorganisms and the highest 

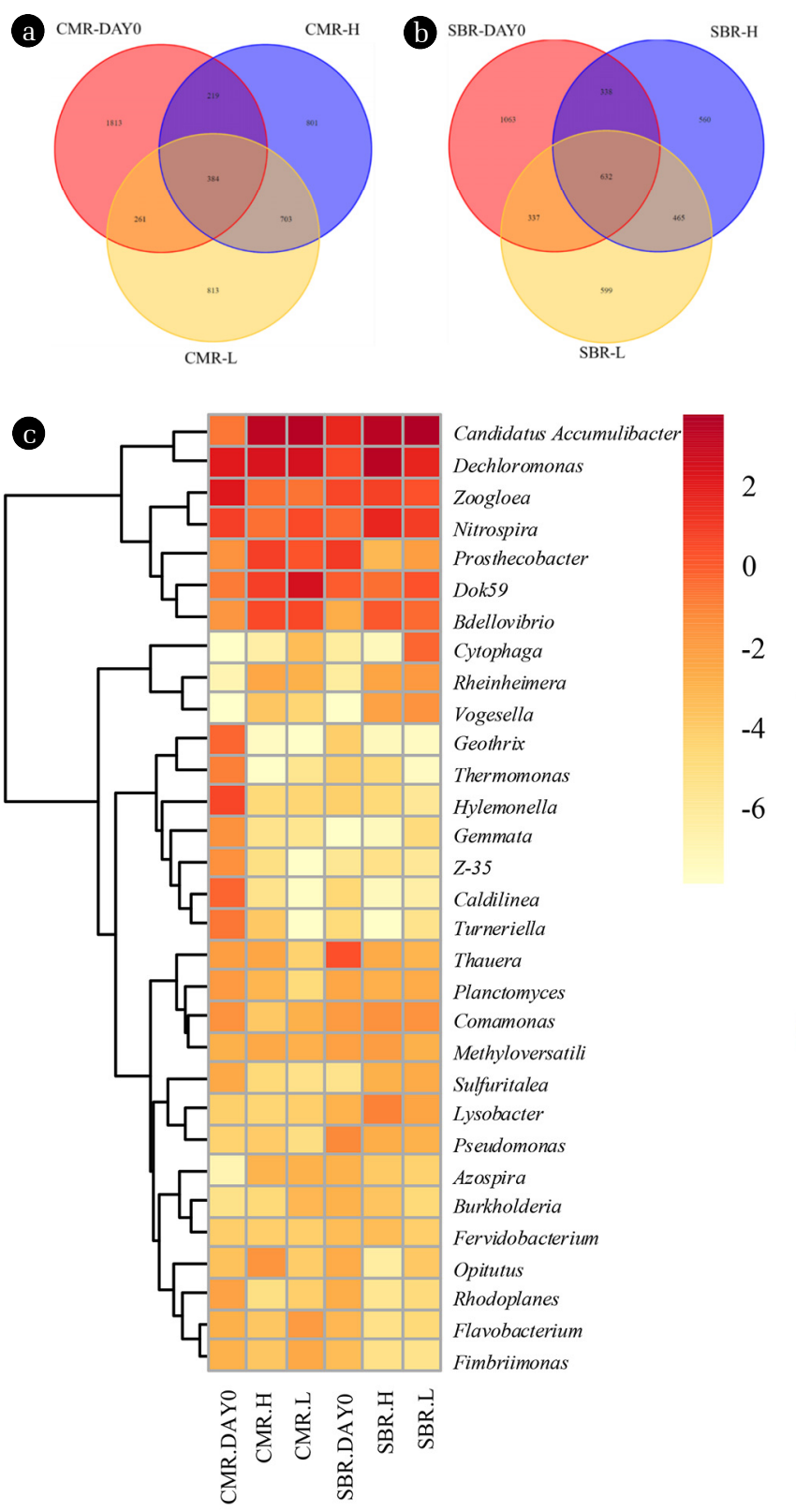
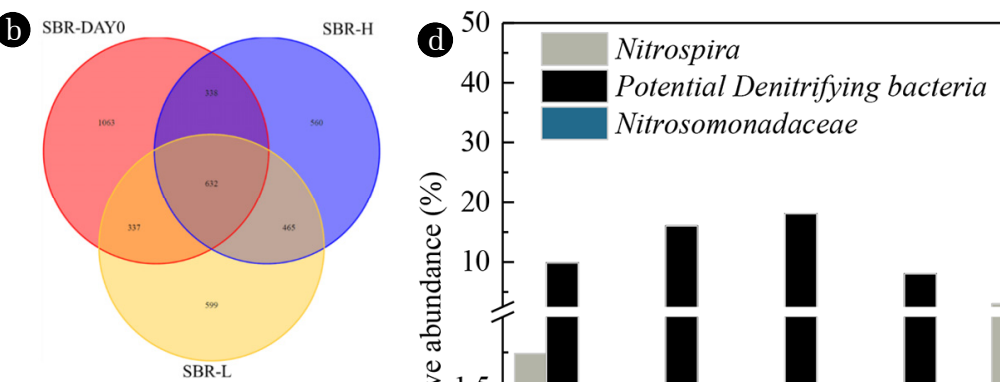

0.0

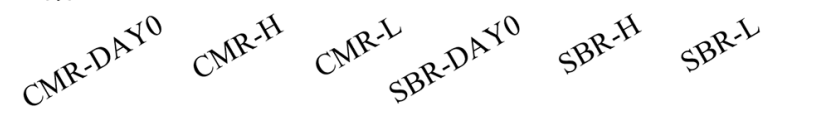

$-4$

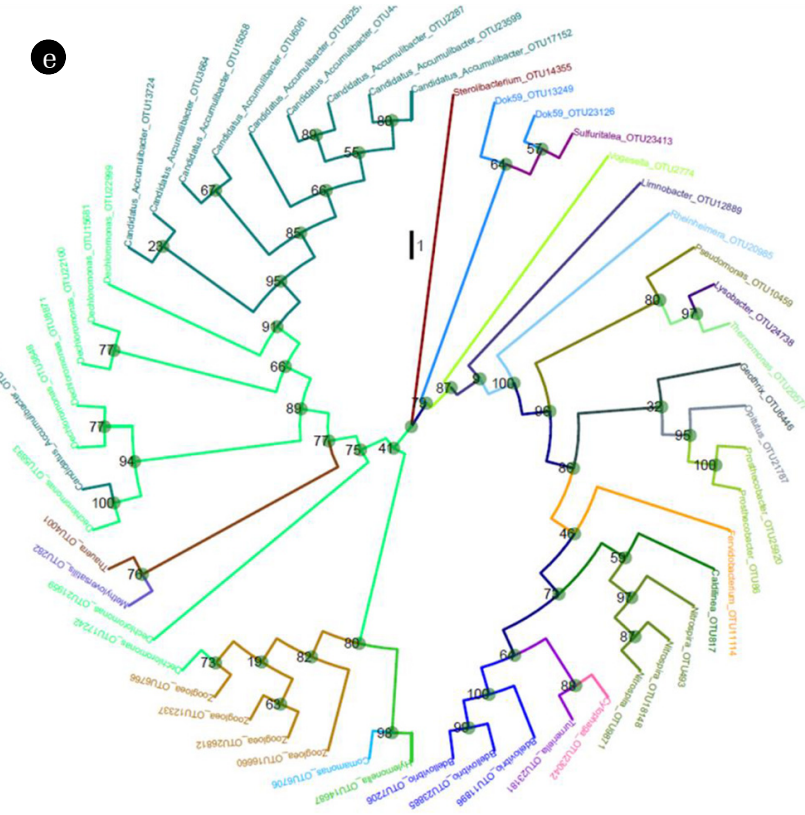

Fig. 2. Species sharing in CMR systems (a) and SBR systems (b); Microbial community (c); Abundances of nitrifiers and denitrifiers (d); Phylo-tree of top 50 genera (e).

producer and reducers ratio of SBR-L could be a response for high $\mathrm{N}_{2} \mathrm{O}$ emission during denitrification. The low abundances of $\mathrm{N}_{2} \mathrm{O}$ reducers and the high microbial diversity in CMR systems might be the reason for high $\mathrm{N}_{2} \mathrm{O}$ emission during nitrification in the presence of organics.

\section{Conclusions}

The present study attempted to explore similarities and differences between SBR and CMR systems from nitrogen removal,
$\mathrm{N}_{2} \mathrm{O}$ emission and microbial diversity. CMR systems had obviously higher nitrogen removal capacity over SBR systems. SBR systems enriched nitrifiers and denitrifiers with high specific activities. More $\mathrm{N}_{2} \mathrm{O}$ emission was observed for CMR during nitrification, whereas for SBR during denitrification. More microbial diversity was observed in CMR systems. The dominant DNPAOs and low abundances of $\mathrm{N}_{2} \mathrm{O}$ reducers might be responsible for $\mathrm{N}_{2} \mathrm{O}$ emission during nitrification and denitrification. 


\section{Acknowledgments}

This research was supported by the Major Science and Technology Program for Water Pollution Control and Treatment of China (2018ZX07604-001) and the Development and Reform Commission of Shenzhen Municipality (urban water recycling and environment safety program).

\section{References}

1. Sun Y, Guan Y, Pan M, Zhan X, Hu Z, Wu G. Enhanced biological nitrogen removal and $\mathrm{N}_{2} \mathrm{O}$ emission characteristics of the intermittent aeration activated sludge process. Rev. Environ. Sci. Bio/Technol. 2017;16:1-20.

2. Wang H, Guan Y, Li L, Wu G. Characteristics of biological nitrogen removal in a multiple anoxic and aerobic biological nutrient removal process. Biomed Res. Int. 2015;2015:531015.

3. Ge S, Peng Y, Qiu S, Zhu A, Ren N. Complete nitrogen removal from municipal wastewater via partial nitrification by appropriately alternating anoxic/aerobic conditions in a continuous plug-flow step feed process. Water Res. 2014;55: 95-105

4. Gilbert EM, Agrawal S, Brunner F, Schwartz T, Horn H, Lackner S. Response of different Nitrospira species to anoxic periods depends on operational DO. Environ. Sci. Technol. 2014;48:2934-2941.

5. Wunderlin P, Mohn J, Joss A, Emmenegger L, Siegrist H. Mechanisms of $\mathrm{N}_{2} \mathrm{O}$ production in biological wastewater treatment under nitrifying and denitrifying conditions. Water Res. 2012;46:1027-1037.

6. Peng L, Ni BJ, Ye L, Yuan Z. The combined effect of dissolved oxygen and nitrite on $\mathrm{N}_{2} \mathrm{O}$ production by ammonia oxidizing bacteria in an enriched nitrifying sludge. Water Res. 2015;73:29-36.

7. Wang H, Guan Y, Pan M, Wu G. Aerobic $\mathrm{N}_{2} \mathrm{O}$ emission for activated sludge acclimated under different aeration rates in the multiple anoxic and aerobic process. J. Environ. Sci. 2016;43:70-79.

8. Sun Y, Wang H, Wu G, Guan Y. Nitrogen removal and nitrous oxide emission from a step-feeding multiple anoxic and aerobic process. Environ. Technol. 2017;39:814-823.

9. Sims A, Gajaraj S, Hu Z. Nutrient removal and greenhouse gas emissions in duckweed treatment ponds. Water Res. 2013;47:1390-1398.

10. Terada A, Sugawara S, Yamamoto T, Zhou S, Koba K, Hosomi M. Physiological characteristics of predominant ammonia-oxidizing bacteria enriched from bioreactors with different influent supply regimes. Biochem. Eng. J. 2013;79:153-161.

11. Liang W, Chao Y, Ren H, Geng J, Ding L, Ke X. Minimization of nitrous oxide emission from CASS process treating low carbon source domestic wastewater: Effect of feeding strategy and aeration rate. Bioresour. Technol. 2015;198:172-180.

12. Kim DJ, Kim SH. Effect of nitrite concentration on the distribution and competition of nitrite-oxidizing bacteria in nitratation reactor systems and their kinetic characteristics. Water Res. 2006;40:887-894.
13. Chandran K, Stein LY, Klotz MG, van Loosdrecht MC. Nitrous oxide production by lithotrophic ammonia-oxidizing bacteria and implications for engineered nitrogen-removal systems. Biochem. Soc. Trans. 2011;39:1832-1837.

14. Pijuan M, Torà J, Rodríguezcaballero A, César E, Carrera J, Pérez J. Effect of process parameters and operational mode on nitrous oxide emissions from a nitritation reactor treating reject wastewater. Water Res. 2014;49:23-33.

15. Gong YK, Peng YZ, Yang Q, Wu WM, Wang SY. Formation of nitrous oxide in a gradient of oxygenation and nitrogen loading rate during denitrification of nitrite and nitrate. $J$. Hazard. Mater. 2012;227-228:453-460.

16. Smolders GJF, Van der Meij J, Van Loosdrecht MCM, Heijnen JJ. Model of the anaerobic metabolism of the biological phosphorus removal process: Stoichiometry and $\mathrm{pH}$ influence. Biotechnol. Bioeng. 1994;43:461-470.

17. APHA. Standard methods for the examination of water and wastewater. Washington: American Public Health Association; 1995.

18. Kimochi Y, Inamori Y, Mizuochi M, Xu KQ, Matsumura M. Nitrogen removal and $\mathrm{N}_{2} \mathrm{O}$ emission in a full-scale domestic wastewater treatment plant with intermittent aeration. J. Ferment. Bioeng. 1998;86:202-206.

19. Caporaso JG, Lauber CL, Walters WA, et al. Global patterns of 16S rRNA diversity at a depth of millions of sequences per sample. Proc. Natl. Acad. Sci. USA 2011;108:4516-4522.

20. Liu Y, Shi H, Xia L, et al. Study of operational conditions of simultaneous nitrification and denitrification in a carrousel oxidation ditch for domestic wastewater treatment. Bioresour. Technol. 2010;101:901-906.

21. Chen AC, Chang JS, Yang L, Yang YH. Nitrogen removal from sewage by continuous flow SBR system with intermittent aeration. Environ. Technol. 2001;22:553-559.

22. Mosquera-Corral A, Gonzalez F, Campos JL, Méndez R. Partial nitrification in a SHARON reactor in the presence of salts and organic carbon compounds. Process Biochem. 2005;40: 3109-3118.

23. Sun Y, Guan Y, Wang D, Liang K, Wu G. Potential roles of acyl homoserine lactone based quorum sensing in sequencing batch nitrifying biofilm reactors with or without the addition of organic carbon. Bioresour. Technol. 2018;259:136-145.

24. Pan M, Wen X, Wu G, Zhang M, Zhan X. Characteristics of nitrous oxide $\left(\mathrm{N}_{2} \mathrm{O}\right)$ emission from intermittently aerated sequencing batch reactors (IASBRs) treating slaughterhouse wastewater at low temperature. Biochem. Eng. J. 2014;86: 62-68.

25. Shen L, Guan Y, Wu G. Effect of heterotrophic activities on nitrous oxide emission during nitrification under different aeration rates. Desalination. Water Treat. 2015;55:821-827.

26. Wang H, Sun Y, Wu G, Guan Y. Effect of anoxic to aerobic duration ratios on nitrogen removal and nitrous oxide emission in the multiple anoxic/aerobic process. Environ. Technol. 2018; doi.org/10.1080/09593330.2018.1427801.

27. Tallec G, Garnier J, Billen G, Gousailles, M. Nitrous oxide emissions from denitrifying activated sludge of urban wastewater treatment plants, under anoxia and low oxygenation. Bioresour. Technol. 2008;99:2200-2209. 
28. Gabarró J, González-Cárcamo P, Ruscalleda M, et al. Anoxic phases are the main $\mathrm{N}_{2} \mathrm{O}$ contributor in partial nitritation reactors treating high nitrogen loads with alternate aeration. Bioresour. Technol. 2014;163:92-99.

29. Wang Q, Jiang G, Ye L, Pijuan M, Yuan Z. Heterotrophic denitrification plays an important role in $\mathrm{N}_{2} \mathrm{O}$ production from nitritation reactors treating anaerobic sludge digestion liquor. Water Res. 2014;62:202-210.

30. Cığgın AS, Rossetti S, Majone M, Orhon D. Effect of feeding and sludge age on acclimated bacterial community and fate of slowly biodegradable substrate. Bioresour. Technol. 2011;102:7794-7801.

31. Jia W, Zhang J, Xie H, et al. Effect of PHB and oxygen uptake rate on nitrous oxide emission during simultaneous nitrification denitrification process. Bioresour. Technol. 2012;113: 232-238.

32. Lemaire R, Meyer R, Taske A, Crocetti GR, Keller J, Yuan Z. Identifying causes for $\mathrm{N}_{2} \mathrm{O}$ accumulation in a lab-scale sequencing batch reactor performing simultaneous nitrification, denitrification and phosphorus removal. $J$. Biotechnol. 2006;122:62-72.

33. Zhou Y, Pijuan M, Zeng RJ, Yuan Z. Free nitrous acid inhibition on nitrous oxide reduction by a denitrifying-enhanced biological phosphorus removal sludge. Environ. Sci. Technol. 2008;42:8260-8265.

34. Zeng RJ, Lemaire R, Yuan Z, Keller J. Simultaneous nitrification, denitrification, and phosphorus removal in a lab-scale sequencing batch reactor. Biotechnol. Bioeng. 2003;84:170-178.

35. Kim JM, Lee HJ, Kim SY, Song JJ, Park W, Jeon CO. Analysis of the fine-scale population structure of "Candidatus Accumulibacter phosphatis" in enhanced biological phosphorus removal sludge, using fluorescence in situ hybridization and flow cytometric sorting. Appl. Environ. Microbiol. 2010;76:3825-3835.

36. Lv XM, Shao MF, Li J, Li CL. Metagenomic analysis of the sludge microbial community in a lab-scale denitrifying phosphorus removal reactor. Appl. Biochem. Biotechnol. 2015;175: 3258-3270.

37. Feng S, Tan CH, Constancias F, Kohli GS, Cohen Y, Rice SA. Predation by Bdellovibrio bacteriovorus significantly reduces viability and alters the microbial community composition of activated sludge flocs and granules. FEMS Microbiol. Ecol. 2017;93.

38. Yang C, Zhang W, Liu R, et al. Phylogenetic diversity and metabolic potential of activated sludge microbial communities in full-scale wastewater treatment plants. Environ. Sci.
Technol. 2011;45:7408-7415.

39. Wang X, Hu M, Xia Y, Wen X, Ding K. Pyrosequencing analysis of bacterial diversity in 14 wastewater treatment systems in china. Appl. Environ. Microbiol. 2012;78:7042-7047.

40. Takeda M, Yoneya A, Miyazaki Y, et al. Prosthecobacter fluviatilis sp. nov., which lacks the bacterial tubulin btubA and btubB genes. Int. J. Syst. Evol. Microbiol. 2008;58:1561-1565.

41. Winkler MH, Boets P, Hahne B, Goethals P, Volcke EI. Effect of the dilution rate on microbial competition: r-strategist can win over k-strategist at low substrate concentration. Plos One 2017;12:e0172785.

42. Park HD, Noguera DR. Nitrospira community composition in nitrifying reactors operated with two different dissolved oxygen levels. J. Microbiol. Biotechnol. 2008;18:1470-1474.

43. Chain P, Lamerdin J, Larimer F, et al. Complete genome sequence of the ammonia-oxidizing bacterium and obligate chemolithoautotroph Nitrosomonas europaea. J. Bacteriol. 2003;185:2759-2773.

44. Shapleigh JP. The denitrifying prokaryotes. The Prokaryotes. 2006. p. 769-792.

45. Lu H, Chandran K, Stensel D. Microbial ecology of denitrification in biological wastewater treatment. Water Res. 2014;64:237-254.

46. Zheng M, Tian Y, Liu T, et al. Minimization of nitrous oxide emission in a pilot-scale oxidation ditch: generation, spatial variation and microbial interpretation. Bioresour. Technol. 2015;179:510-517.

47. Etchebehere C, Errazquin MI, Dabert P, Moletta R, Muxí L. Comamonas nitrativorans sp. nov., a novel denitrifier isolated from a denitrifying reactor treating landfill leachate. Int. J. Syst. Evol. Microbiol. 2001;51:977-983.

48. Yoon H, Song MJ, Yoon S. Design and feasibility analysis of a self-sustaining biofiltration system for removal of low concentration $\mathrm{N}_{2} \mathrm{O}$ emitted from wastewater treatment plants. Environ. Sci. Technol. 2017;51:10736-10745.

49. Lyu W, Huang L, Xiao G, Chen Y. Effects of carbon sources and $\operatorname{cod} / \mathrm{n}$ ratio on $\mathrm{N}_{2} \mathrm{O}$ emissions in subsurface flow constructed wetlands. Bioresour. Technol. 2017;245:171-181.

50. Strand SE, Mcdonnell AJ, Unz RF. Oxygen and nitrate reduction kinetics of a nonflocculating strain of Zoogloea ramigera. Antonie Van Leeuwenhoek 1998;54:245-255.

51. Sheng X, Liu R, Song X, Chen L, Tomoki K. Comparative study on microbial community in intermittently aerated sequencing batch reactors (SBR) and a traditional SBR treating digested piggery wastewater. Front. Environ. Sci. Eng. 2017;11:97-103. 